\title{
Persepsi followers @ perpuseru terhadap akun instagram PerpuSeru menggunakan teori decoding-encoding
}

\author{
Lasenta Adriyana1, Kuncoro Darumoyo ${ }^{2}$ \\ ${ }^{1}$ Manajemen Informasi dan Perpustakaan, Universitas Gadjah Mada \\ Jl. Teknika Utara, Sleman, Yogyakarta, 55281 \\ 2Ilmu Keolahragaan, Universitas Negeri Surabaya \\ Jl. Ketintang No. 30, Surabaya, Jawa Timur, 60213 \\ E-mail: ${ }^{1}$ lasenta16@gmail.com, ${ }^{2}$ darumoyokuncoro@gmail.com
}

Received: November 2018; Accepted: December 2018; Published: December 2018

\begin{abstract}
Libraries have used media development as part of the culture to influence people to use the library. An example of the use of media as a means of mediation is the PerpuSeru program. Previously, this program partnered with 34 libraries, but currently, the PerpuSeru program has partnered with more than 400 libraries and reading parks in Indonesia. One of the media used in transferring information is Instagram; PerpuSeru has an Instagram account namely @perpuseru in which various information about the PerpuSeru program is available and the extent to which the program is running. The purpose of this study was to determine the extent of the followers' perceptions in receiving information provided on the @ perpuseru Instagram by decoding-encoding theory, to examine the extent this theory developed in a media in the present era, and the role the theory played in the media. This study used the descriptive qualitative research method by interviewing some followers of the @perpuseru account. The result found two different views from followers, namely followers with a hegemonic dominant point of view who accepted all the content of information conveyed, and others with a negative perspective who had other considerations in receiving information on the posts of @perpuseru account. However, there were no followers with optional viewpoints. It can be concluded that the two perspectives of @perpuseru Instagram followers are the hegemonic and negative perspective.
\end{abstract}

Keywords: Decoding-encoding theory; Follower; Perpuseru

\begin{abstract}
Abstrak
Berkembangnya media sebagai bagian dari budaya di masyarakat juga dimanfaatkan oleh perpustakaan sebagai salah satu cara untuk mempengaruhi masyarakat agar memanfaatkan perpustakaan. Satu contoh kasus dari pemanfaatan media sebagai sarana penghubung adalah program PerpuSeru. Program ini dulunya bermitra dengan 34 perpustakaan saja, namun saat ini program PerpuSeru telah bermitra hingga lebih dari 400 perpustakaan dan taman baca di Indonesia. Salah satu media yang digunakan dalam mentransfer informasi adalah instagram. PerpuSeru memiliki akun instagram yaitu @perpuseru didalamnya terdapat berbagai informasi tentang program PerpuSeru dan sejauh mana program tersebut berjalan. Tujuan penelitian ini adalah untuk melihat sejauh mana persepsi followers dalam menerima informasi yang diberikan dalam instagram @perpuseru dengan mengacu pada teori decoding-encoding, hal ini untuk melihat sejauh mana teori ini berkembang dalam sebuah media di era normal baru saat ini serta bagaimana teori berperan dalam sebuah media. Artikel ini meggunakan metode penelitian kualitatif deskriptif dengan wawancara pada beberapa followers akun @perpuseru. Hasilnya terdapat dua perbedaan pandangan dari followers, yaitu terdapat followers dengan sudut pandang dominan hegemonic yaitu followers yang menerima segala isi informasi yang disampaikan serta sebagian lainnya memiliki sudut pandang negociate yaitu followers yang memiliki pertimbangan lain dalam menerima informasi pada postingan yang ada di akun @perpuseru, namun tidak terdapat followers dengan sudut pandang opsional.
\end{abstract}

Kata Kunci: Teori decoding-encoding; Followers; Perpuseru

doi: https://dx.doi.org/10.24198/jkip.v2i6.19336

(C) 2018 Jurnal Kajian Informasi \& Perpustakaan. This is an open access article under the CC BY-SA license

Website: http://jurnal.unpad.ac.id/jkip 


\section{PENDAHULUAN}

Berkembangnya teknologi informasi mendorong semua bagian masyarakat untuk berinovasi melalui media-media yang telah tersedia atau bahkan mengembangkannya. Masyarakat melalui internet dan media sosial dapat terhubung dengan mudah satu sama lain. Menurut Rusmana (2015), Watie (2016) dan Rianto (2016) media sosial memiliki kemampuan untuk menampilkan pesan berupa lambang verbal dan nonverbal serta interaktivitas yang tinggi sebagai media baru dengan kontrol aktif dari penggunanya itu sendiri.

Salah satunya adalah media sosial instagram. Instagram menawarkan berbagai bentuk konten visual seperti foto dan video dalam postingannya. Menurut Adi dan Ali (2017), tidak kurang empat puluh lima juta penduduk Indonesia aktif menggunakan media sosial instagram. Berdasarkan jumlah tersebut Indonesia menjadi pasar terbesar instagram di Asia dengan 700 pengguna aktif setiap bulannya.

Begitu masifnya penggunaan instagram di Indonesia, tidak sedikit individu dan organisasi yang memanfaatkannya sebagai media berbagi informasi, promosi hingga bisnis. Tak terkecuali di perpustakaan. Perpustakaan sebagai salah satu organisasi yang fokus pada pelayanan masyarakat dan pengembangan informasi serta pengetahuan masyarakat, tentunya membutuhkan media untuk menunjang itu semua. Umumnya perpustakaan menggunakan pamflet atau ulasan di majalah untuk membagi informasi dan mempromosikan diri mereka. Berbeda dengan era saat ini, perpustakaan berkembang dan sadar akan penggunaan media baru seperti media sosial sebagai sarana promosi.

Media menjadi bagian penting bagi pengembangan sebuah organisasi jika ingin dikenal luas oleh masyarakat. Perpustakaan sebagai organisasi publik sudah seharusnya berorientasi pada publik dengan mengedepankan layanan yang dapat dijangkau semua kalangan. Sekarang ini, terdapat berbagai macam media yang dapat digunakan, baik televisi, media sosial, media cetak, bahkan media berbasis videografi seperti youtube. Organisasi tinggal menggunakan daya kreatifitasnya sesuai sasaran yang ingin dicapai.

Selain itu, organisasi dapat memanfaatkan media untuk menyampaikan perkembangannya informasi pada masyarakat luas. Salah satunya ialah program pengembangan perpustakaan dalam akun instagram, bernama @perpuseru. Akun tersebut merupakan bagian dari pengembangan perpustakaan yang merupakan program dari Coca-cola Foundation dan Bill and Melinda Gates Foundation sejak tahun 2011. Program PerpuSeru bertujuan untuk menjadikan perpustakaan sebagai pusat akses teknologi dan informasi (Kartikasari, 2012, Safira, Saleh, \& Suprapto, 2015, Tunardjo, 2018).

Salah satu layanan yang dimiliki PerpuSeru untuk mitra programnya adalah peer learning meeting di perpustakaan, melalui layanan ini ada jembatan antar mitra PerpuSeru untuk saling berkomunikasi dan bertukar pikiran (Ahmad, 2018). Layanan ini membuktikan bahwa perlunya fasilitas berupa media untuk bertukar informasi antar pengguna maupun untuk masyarakat umumnya. Perpustakaan memiliki banyak fungsi sebagai pusat penyebaran informasi bagi 
penggunanya (Safira, Saleh, \& Suprapto, 2015, Krisbiantoro, Suyanto, \& Luthfi, 2015, Subrata, 2009).

Akun @perpuseru memiliki lima ribu lebih followers yang sebagian besar adalah anak muda. Melalui akun tersebut secara konsisten PerpuSeru membagi konten terakit programnya yaitu pengembangan perpustakaan desa dan daerah di Indonesia. Konten yang ditampilkan dalam akun@perpuseru terlihat menarik dan informatif serta mendorong pengguna untuk melihatnya. Hal ini menjadi salah satu daya tarik untuk meningkatkan followers. Hal lain yang dapat menjadi daya tarik adalah adanya artis Ringgo A. Rahman dan Adinia Wirasti yang muncul pada postingan akun @perpuseru.

Media menjadi mediatisasi antara program perpustakaan PerpuSeru dan followers, sebelum adanya instagram program PerpuSeru belum menjadi bahasan yang aktif di kalangan pegiat perpustakaan. Namun adanya akun media sosial khususnya instagram, masyarakat lebih mengenal PerpuSeru dan sejauh mana kontribusinya untuk Indonesia.

Banyaknya followers akun @perpuseru dipersepsikan bahwa PerpuSeru adalah akun yang menarik dan inovatif sehingga pengguna instagram tertarik untuk mengikutinya. Penulis melalui akun ini, ingin melihat bagaimana persepsi followers terhadap isi postingan atau informasi yang diterbitkan oleh PerpuSeru melalui media sosial instagram. Terkait dengan bagaimana persepsi followers mengikuti akun tersebut, melalui teori decodingencoding dari Stuart Hall artikel ini mengulas tentang bagaimana persepsi followers menerima informasi melalui postingan akun @perpuseru.

Media sosial sendiri di Indonesia telah diatur dalam Peraturan Menteri
Pendayaguanaan Aparatur Negara dan Birokrasi RI No 83 Tahun 2012 tentang Pemanfaatan Media Sosial Instansi Pemerintah yaitu pemanfaatan media sosial telah membentuk dan mendukung cara baru dalam berkomunikasi, berinteraksi dan berkolaborasi (Kementerian Pendayagunaan Aparatur Negara dan Reformasi Birokrasi Republik Indonesia, 2012). Diaturnya media sosial dalam peraturan menteri menegaskan bahwa media sosial telah dianggap sebagai bagian dari media komunikasi yang diakui. Saat ini pengguna media sosial bukan hanya untuk kalangan pribadi namun juga organisasi, instansi baik swasta maupun pemerintahan.

Media sosial sangat bermanfaat sekali bagi masyarakat untuk berkenalan dengan orang lain dari luar wilayahnya bertempat tinggal, misal penelitian Galih (2018), mengenai pemanfaatan grup Facebook Backpaker Dunia bagi masyarakat yang akan berpetualang. Selain itu, Permana, Yusup, \& Kurniasih (2016) pun menggunakan media sosial Line sebagai media pencarian informasi oleh mahasiswa BEM FIKOM UNPAD.

Adanya berbagai media sosial yang digunakan sebagai sumber informasi menjadikan masyarakat melimpah informasi dari berbagai sumber, contohnya dalam penggunaan instagram. Berikut survey penggunaan media sosial instagram yang dilakukan pada bulan Januari. Dilihat dari sisi usia pengguna, keaktifan, serta jenis kelamin.

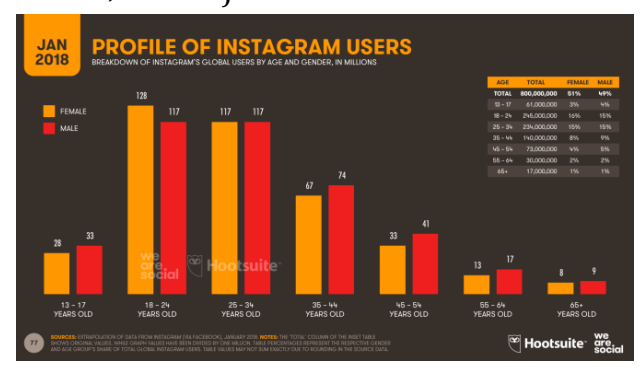

Gambar 1. Pengguna aktif instagram Sumber: Statista, 2018 
Berdasarkan hasil gambar di atas, instagram sendiri di Indonesia memiliki pengikut yang sangat banyak yaitu lebih dari 45 ribu pengguna aktif pada bulan Januari 2018. Baik perempuan maupun laki-laki semua menggunakan instagram dalam mencari informasi. Terlihat dari rentang usia 13 tahun hingga di atas 65 tahun semua menggunakan instagram sebagai bagian dari cara mereka bersosialisasi.

Instagram menjadi media sosial yang dapat digunakan oleh semua kalangan, mulai dari gen a sampai babby bomers (Akçayir, Dündar, \& Akçayir, 2016), namun presentase penggunaan terbanyak adalah pada net gen yaitu umur 18 sampai 34 tahun. Instagram dipandang sebagai media sosial yang banyak digunakan oleh anak muda karena konten utama dari instagram adalah visual atau gambar, sehingga saat ini banyak organisasi dan instansi yang juga menggunakan instagram dalam membagikan informasi pada masyarakat. Instagram menjadi media sosial favorit kaum muda dan dianggap cocok serta cepat membagi informasi pada mereka.

Penggunaan instagram oleh organisasi tertentu juga dianggap lebih cepat dalam menyampaikan informasi terkini. Hal ini dikarenakan mudahnya mengakses instagram dan hampir seluruh masyarakat memiliki instagram. Tidak dapat dipungkiri, perkembangan media dalam era normal baru saat ini mengharuskan organisasi manapun untuk kreatif dalam menggunakannya. Informasi yang dianggap terkini dan terbaru akan cepat viral dan menyebar bahkan dalam hitungan menit. Disamping itu, perlu disadari juga bahwa banyak juga berita atau informasi yang tidak sesuai dengan perkembangan media saat ini.
Salah satu organisasi yang menggunakan instagram dalam mengtransfer informasi pada pengikutnya adalah PerpuSeru. Akun @perpuseru adalah akun organisasi pengembang perpustakaan yang aktif berbagi konten di instagram. Akun@ @perpuseru memanfaatkan media sosial instagram dalam menyampaikan informasi terkait dunia perpustakaan yang sedang dikembangkan di seluruh desa di Indonesia pada pengikutnya. Selain instagram PerpuSeru, media sosial lainnya, seperti facebook, twitter, dan juga telah memiliki website yang semuanya berisi informasi tentang PerpuSeru.

PerpuSeru sendiri adalah program pengembangan perpustakaan di desa dan daerah di Indonesia yang merupakan bagian dari program Coca-cola Foundation dan Bill and Melinda Gates. Program ini bertujuan untuk menjadikan perpustakaan sebagai pusat belajar dan berkegiatan masyarakat berbasis teknologi informasi dan komunikasi. Program PerpuSeru sendiri memiliki tujuan untuk mengurangi kemiskinan informasi dengan mentransformasi perpustakaan daerah dan desa menuju pusat informasi pembelajaran yang menjawab kebutuhan masyarakat melalui peningkatan akses terhadap teknologi. Sesuai dengan tujuan berdirinya program ini, PerpuSeru juga memanfaatkan teknologi sebagai media untuk menarik masyarakat lebih luas guna mendapat informasi lebih banyak tentang PerpuSeru. PerpuSeru memiliki visi yaitu memberdayakan masyarakat Indonesia untuk menghasilkan perubahan sosial yang positif dengan transformasi perpustakaan umum yang terbuka dan dapat diakses pengetahuan dan pembelajarannya (Perpuseru, 2017). 
Program PerpuSeru sudah ada sejak tahun 2011 sehingga program ini masih tergolong baru di Indonesia. Program PerpuSeru berkontribusi untuk membangun perpustakaan di daerah menjadi lebih baik, tentu saja diimbangi dengan kesiapan perpustakaan daerah tersebut dalam menerima pembangunan perpustakaannya. Pemilihan perpustakaan desa atau daerah yang akan menerima bantuan program dilakukan oleh perpustakaan provinsi yang terlebih dahulu telah dilakukan survei pada perpustakaan yang siap menerima bantuan program.

PerpuSeru memiliki inovasi yang unik dalam membagikan informasi terkait program-programnya pada pengikutnya. PerpuSeru memiliki website resmi yang telah lama diluncurkan, kemudian akun facebook, akun twitter, serta akun instagram yang selalu aktif. Media sosial digunakan sebagai jembatan komunikasi pada pengikutnya agar pengembangan program tersampaikan dengan baik serta memberi motivasi lebih pada masyarakat Indonesia dalam pembangunan perpustakaan. Informasi yang disampaikan di media sosial juga berfungsi sebagai penyalur informasi pada daerah-daerah yang membutuhkan bantuan untuk perpustakaan melalui masyarakat yang aktif, yaitu generasi muda.

Dilihat melalui perkembangan media sosial saat ini, penggunaan instagram cukup diminati dan relatif digunakaan oleh semua kalangan. Penggunanya juga cukup banyak, meskipun pengikutnya masih di bawah facebook. Hadirnya instagram PerpuSeru menjadikan sebagai media komunikasi pada masyarakat luas. Komunikasi sendiri diartikan sebagai, "Proses, pesan, atau pengaruh secara khusus dari pemilik informasi pada penggunanya" (Rakhmat, 2009).

\section{METODE PENELITIAN}

Metode yang digunakan dalam tulisan ini adalah pendekatan kualitatif dengan deskriptif. Kualitatif deskriptif adalah riset yang menggunakan pendekatan induktif untuk analisanya (Moleong, 2010). Analisa yang dilakukan dalam penelitian ini bersumber dari wawancara terhadap narasumber dan menggunakan berbagai sumber referensi ilmiah seperti artikel ilmiah, berita serta website.

Wawancara adalah percakapan dengan maksud tertentu, dilakukan oleh dua pihak yaitu interviewer pada interviewee yang memberikan jawaban atas pertanyaan itu. Wawancara dilakukan pada narasumber, yaitu followers akun @perpuseru. Populasi penelitian adalah 8025 followers sehingga narasumber yang dipilih berjumlah 8 orang dan dipilih secara random, katagori yang diberikan pada narasumber di sini adalah followers aktif dan berlatar belakang pendidikan ilmu perpustakaan dan berusia kurang dari 25 tahun. Wawancara pada narasumber berperan sebagai alat pengumpul data yang nantinya akan dikembangkan dalam pembahasan (Moleong, 2010). Adapun profil narasumber adalah sebagai berikut.

Tabel 1. Profil narasumber

\begin{tabular}{lll}
\hline Narasumber 1 & Narasumber 2 & Narasumber 3 \\
\hline Mahasiswa & Pustakawan & CSR PerpuSeru \\
23 Tahun & 25 Tahun & 23 Tahun \\
Malang & Malang & Sidoarjo \\
Followers & Followers & Followers \\
@perpuseru & @perpuseru & @perpuseru \\
sudah 3 tahun & sudah 5 tahun & sudah 5 tahun \\
\hline Narasumber 4 & Narasumber 5 & Narasumber 6 \\
\hline Mahasiswa & Pustakawan & Pustakawan \\
23 Tahun & 24 Tahun & 23 Tahun \\
Sidoarjo & Bandung & Malang \\
Followers & Followers & Followers \\
@perpuseru 6 & @perpuseru & @perpuseru \\
Bulan & sudah 4 tahun & sudah 3 tahun \\
\hline
\end{tabular}




\begin{tabular}{ll}
\hline Narasumber 7 & Narasumber 8 \\
\hline Mahasiswa & Mahasiswa \\
25 Tahun & 21 Tahun \\
Medan & Malang \\
Followers & Followers \\
@perpuseru & @perpuseru \\
sudah 2 tahun & sudah 4 tahun \\
\hline
\end{tabular}

Sumber: Hasil penelitian, 2018

Setelah wawancara selesai dilakukan, maka hasil wawancara di analisis dengan menggunakan teori decoding-encoding dan melihat sejauh mana teori tersebut stand up sebagai mediatisasi informasi pada media instagram ke followers. Melalui teori decoding-encoding, akan diketahui bagaimana followers memaknai pesan sebagai informasi dari @perpuseru.

Analisis dilakukan dengan cara mencatat hasil di lapangan, kemudian memilah dan mengklasifikasikannya berdasarkan kategori yang telah ditentukan, serta membuat jalan dengan mendeskripsikannya agar hasil penelitian mempunyai makna dengan menemukan pola dan hubungan (Moleong, 2010).

Penelitian ini mengukur persepsi seseorang dengan teori decoding-encoding dari Stuart Hall. Persepsi sendiri menurut Firdayanti (2012), adalah bagaimana seseorang memilih, mengorganisasi, dan menginterpretasi rangsangan pada dirinya dengan bantuan indera menjadi gambaran objek yang memiliki kebenaran subjektif dan memiliki arti tertentu. Pengukuran persepsinya sendiri dilakukan melalui analisis hasil wawancara dan memadukannya dengan teori decoding-encoding.

Beberapa penelitian terdahulu telah membahas tentang instagram dan media sosial lainnya, Darmayanti mengungkapkan bahwa dengan memanfaatkan eksistensi instagram sebagai kekuatan channel komunikasi untuk direct marketing. Humaidah (2017) menyebutkan pemanfaatan media sosial di perpustakaan memiliki korelasi dengan promosi yang dilakukan perpustakaan. Adanya promosi tersebut berdampak pada peningkatang jumlah kunjungan perpustakaan di Kementrian Perindustrian R.I.

Penelitian di atas menegaskan bahwa untuk membentuk suatu persepsi pada sasaran yang ingin dituju dapat melalui media. Pemilihan media yang tepat akan berpengaruh terhadap hasil yang diharapkan. Instagram, maupun media sosial lainnya masing-masing memiliki fungsi serta tujuan yang berbeda sehingga pemanfaatannya akan lebih menyasar pada lingkup tertentu.

Berbagai media sosial yang ada saat ini memiliki ciri khusus dan fungsi masing-masing. Hal tersebut dimaksudkan agar pengguna dapat memilih media sosial mana yang cocok dengan ekspresi mereka. Hal tersebut baiknya juga disadari oleh perpustakaan maupun pengembang perpustakaan untuk membangun perpustakaan yang inovatif dan terbuka dengan dukungan dan penerimaan teknologi terbaru supaya perpustakaan tidak dipandang kuno oleh pengguna perpustakaan. Penggunaan media sosial oleh perpustakaan maupun pengembang perpustakaan dimanfaatkan sebagai salah satu sarana komunikasi dan promosi pada pengguna perpustakaan untuk menyampaikan berbagai informasi terkait organisasi tersebut.

Era normal baru saat ini memungkinkan semua kalangan untuk terbiasa dalam penggunaan media sosial. Hal tersebut seperti kebiasaan sehari-hari yang mudah untuk dilakukan. Situasi berubah dalam 3 dasawarsa terakhir dan menghasilkan perubahan yang cukup besar. Dengan kata lain, situasi ini adalah 
normal, tidak lagi menjadi sesuatu yang menggemparkan. Masyarakat berada di era di mana situasi seperti ini sudah menjadi bagian hidup setelah disrupsi (Khoir, 2018).

Kedatangan internet dan perubahan yang cukup besar dirasakan normal dan berjalan sesuai biasanya. Hal ini menjadi wajar karena perubahan itu datang seiring berjalannya waktu dan perkembangan industri yang semakin cepat. Masyarakat mengikuti perkembangan tersebut dan merasakannya sebagai bagian dari kehidupan normal sehari-hari mereka, yang tak ubahnya adalah media sosial.

\section{HASIL DAN PEMBAHASAN}

Perubahan teknologi mendorong organisasi maupun instansi pemerintah maupun non pemerintah untuk dapat mengikutinya, berubah dan mengadopsi kebaruan teknologi untuk diterapkan dalam organisasinya. Media sosial adalah salah satu media komunikasi dengan teknologi yang hadir dengan dukungan internet. Apalagi dengan hadirnya teknologi layaknya smartphone memudahkan para developer untuk mengembangan media sosial berupa aplikasi.

Melihat hal ini, media-media yang ada ini sesungguhnya adalah sebagai perantara informasi, agar pesan yang ingin disampaikan dapat diterima dengan baik oleh masyarakat luas, meskipun tidak semua masyarakat mengikuti akun @perpuseru namun dapat terwakilkan dengan followers @perpuseru yang sudah mencapai ribuan. Hal ini sesuai dengan gambaran instagram sebagai media promosi perpustakaan, menurut Nurpratama \& Adriyana (2017) menyatakan bahwa instagram diasumsikan akan cocok dengan perpustakaan karena karakteristiknya yang visual di mana dapat menggambarkan atau mewakili perpustakaan untuk menggambarkan secara real kondisi, layanan dan programnya karena media sosial milik organisasi memiliki kecenderungan digunakan sebagai sarana promosi dan komunikasi.

Hal lain yang menjadi daya tarik dari PerpuSeru adalah dikukuhkannya artis Adinia Wirasti sebagai goodwill ambassador atau duta persahabatan PerpuSeru. Selama ini masyarakat mengetahui bahwa Adinia Wirasti adalah artis peran terkenal yang memiliki nama baik dalam dunia seni peran. Ditunjuknya Adinia Wirasti sebagai duta, diharapkan mampu membawa perubahan baik kecil maupun besar dalam kaitannya dengan literasi terutama pada kaum muda di Indonesia, dan masyarakat Indonesia pada umumnya.

PerpuSeru telah memberikan informasi melalui berbagai media sosial pada pengikutnya namun tidak dipungkiri bahwa pengikut media sosial PerpuSeru akan memiliki pemahaman yang tidak sejalan dengan yang telah diinformasikan. Pengikut akun PerpuSeru terutama di instagram memiliki jumlah yang tidak sedikit yaitu lebih dari lima ribu pengikut. Penerima pesan bisa jadi memaknai berbeda dengan apa yang dimaksudkan oleh pemberi pesan karena komunikasi yang terjalin adalah komunikasi satu arah. Hal tersebut tidak menutup kemungkinan karena followers akun @perpuseru merupakan individual aktif sebagai partisipan komunikasi massal yaitu instagram. Pembagian penerima pesan dalam teori decoding-encoding dibagi menjadi dua yaitu reciever dan decoder, followers akun @perpuseru juga dapat memaknai pesan yang disampaikan 
melalui postingan dengan makna yang berbeda-beda.

Teori decoding sesungguhnya tidak bisa lepas dari teori encoding, jadi teori decoding dan encoding menjadi satu kesatuan yang memiliki arti dalam produksi makna. Encoding sendiri adalah suatu pesan mentah yang terjadi di lapangan, kemudian dikemas sedemikian rupa sehingga pesan tersebut bisa disalurkan pada sasaran (Hall, 2001). Selanjutnya setelah pesan tersebut dikemas dengan berbagai bahasa masyarakat sesuai sasaran, pemberi pesan tidak bisa serta merta meyakini bahwa pesan tersebut akan memiliki makna yang sama antar penerima pesan, di sinilah proses docoding terjadi, bahwa penerima pesan tidak selalu menerima pesan sesuai dengan apa yang pemberi pesan sampaikan (Hall, 2001). Adanya interpretasi makna dan pengaruh psikologi dari masing-masing individu memungkinkan makna yang didapat menjadi berbeda-beda arti.

Penerima pesan dalam media apapun, terutama dalam hal ini adalah instagram yaitu followers yang diposisikan secara sosial dengan pembacaan kultural yang sama antara penerima pesan dengan pengirim pesan, mereka akan mengodekan pesan tersebut di dalam kerangka kerja yang sama. Namun, ketika penerima pesan dikondisikan berbeda secara sosial maka penerima pesan akan mampu mengode pesan dengan cara alternatif (Hall, 2011). Dalam penerimaan pesan atau decoding dari pengirim pesan dalam hal ini adalah akun @perpuseru terhadap penerima pesan yaitu followers dimulai dari momen pertama yaitu produksi maknanya atau disebut proses encoding, momen kedua adalah hasilnya yaitu teks atau program yang memiliki makna lebih, kemudian momen ketiga adalah proses pemaknaan makna tersebut atau decoding.

Proses encoding terdapat tiga hal yang sangat berperan, yang pertama framework of knowlegde adalah bingkai pengetahuan misalnya proses promosi pengembangan perpustakaan oleh PerpuSeru melalui instagram. Organisasi ini memiliki pengetahuan apa terkait pengembangan perpustakaan, tentang bagaimana cara kerja pengembangan tersebut dan apa yang harus dilakukan agar pengembangan perpustakaan dapat berjalan sebagaimana yang diharapkan. Kedua, relation of production adalah relasi kuasa dalam memproduksi sebuah makna, misalnya akun @perpuseru yang menonjolkan Cocacola Foundation serta Bill and Melinda Gates Foundation di setiap profilnya. Hal ini bertujuan untuk menyampaikan pesan lebih dalam karena semua orang pasti tau siapa Bill dan Melinda Gates serta bagaimana besarnya Coca-cola Foundation di Indonesia bahkan dunia. Ketiga, technical infrastructure adalah kemampuan teknisnya, misalnya terlihat sekali dalam akun @perpuseru telah menggunakan berbagai filter dan kemampuan fotografi yang baik dalam menampilkan setiap postingannya, yang membuat followers tertarik melihatnya.

Proses encoding tidak lepas dari dominan hegemonic code, yaitu kode-kode hegemonik yang membuat kompleksitas produksi makna menjadi tidak lagi netral sehingga terjadi proses yang dinamakan programing as meaning discourse. Pada akhirnya, penerima pesan akan menerima hal-hal yang berperan dari profesional code. Namun, penerima pesan bisa saja menerima pesan tidak sesuai dengan apa yang diharapkan oleh pemberi pesan. Hall (2011) juga mengatakan, apabila kita ingin 
menundukan media, kita perlu mengetahui bahwa media itu sendiri adalah the meaning power.

Menurut Parkin (2000) dalam Hall (2011), ada tiga model diantaranya, posisi penerima pesan atau decoding, kode yang dinegosiasikan dan kode opsional. penerima pesan atau decoding yakni encoding/ decoding dominan hegemonik yang menerima makna sesuai yang dikehendaki oleh pemberi makna. Dalam kode yang dinegosiasikan, artinya pengakuan atau legitimasi kode hegemonik secara abstrak yang memiliki aturan dan adaptasinya berdasarkan situasi terkait. Lalu dalam kode opsional, di mana orang memahami pemberi pesan atau encoding yang lebih disukai namun menolak lainnya, atau sebaliknya.

Dari ketiga model di atas, kita dapat melihat bagaimana followers dari akun @perpuseru memaknai pesan melalui postingan di instagram @perpuseru. Penerima pesan dapat menjadi dominan hegemonic yang sangat setuju tanpa perlawanan terhadap pesan yang disampaikan, atau negotiated yang setuju namun memiliki opsi lain tentang makna pesan tersebut, atau bahkan opposional yang memaknai pesan tersebut secara berbeda dari pemberi pesan.

Pada penelitian sebelumnya yang dilakukan untuk melihat bagaimana pembaca merepresentasikan hasil informasi yang didapat dari hasil membaca novel dapat dilihat bahwa ketiga model penerima pesan ini terdapat dalam penelitian tersebut (Pujiati, Astutiningsih, \& Sari, 2015). Perbedaan media penelitian tidak menutup kemungkinan untuk menghasilkan model penerimaan pesan yang berbeda. Setelah dilakukan penelitian melalui wawancara maka didapat hasil pembahasan sebagai berikut.
Narasumber dari penelitian ini adalah followers dari akun @perpuseru yang berjumlah 8 orang yang memiliki latar belakang ilmu perpustakaan. Hal ini dikarenakan akun @perpuseru berperan aktif dalam program pengembangan perpustakaan. Batasan narasumber juga berdasarkan keaktifan di media sosial instagram serta berumur kurang dari 25 tahun karena sasaran utamanya adalah kaum muda atau net generation.

Setelah dilakukan wawancara pada 8 narasumber dapat disimpulkan bahwa followers memiliki pemaknaan yang berbeda pada akun PerpuSeru. Followers dengan latar belakang ilmu perpustakaan yang notabene ada dalam dunia perpustakaan memiliki penilaian yang berbeda tentang PerpuSeru yang secara tersirat adalah program pengembangan perpustakaan daerah di Indonesia. Pemaknaan yang terjadi tidak lepas dari teori decoding-encoding Stuart Hall tentang penerima pesan yang membaginya menjadi dua yaitu reciver dan decoder. Reciver adalah orang yang menerima pesan sesuai dengan apa yang diberikan oleh pemberi pesan sedangkan decoder adalah orang yang menerima pesan bisa mendeskripsikan sendiri pesan tersebut.

Wawancara dengan narasumber di atas dapat dikatagorikan dalam tiga model sebagai reading position. Sebagian narasumber sebagai model dominan hegemonic yang artinya narasumber tersebut menerima segala bentuk informasi yang diberikan oleh akun @perpuseru secara setuju tanpa keraguan dan menganggap apa yang ada pada PerpuSeru adalah program terbaik untuk masyarakat umumnya. Awalnya narasumber satu, tidak mengetahui secara pasti apa itu PerpuSeru namun setelah melihat orang terdekatnya ada di dalam 
PerpuSeru dan menjadi followersnya kemudian narasumber satu juga mengikuti akun tersebut. Hal ini juga dapat dilihat dari sisi ISA (Ideologi State Apparuse) yang artinya ada penanaman kesadaran melalui ideologi. Ideologi yang dimaksud adalah bahwa dengan adanya orang terdekat yang mengikuti program tersebut, secara tidak langsung mendorong narasumber untuk ikut dalam program tersebut meskipun belum mengetahui secara pasti apa itu PerpuSeru. Namun dengan mengikuti akun@perpuseru pada akhirnya narasumber satu memiliki pemahaman makna sendiri tentang PerpuSeru meskipun tidak sepenuhnya sesuai dengan pesan yang semula ingin disampaikan oleh @perpuseru.

Hal ini sesuai dengan apa yang dikatakan pada teori bahwa perilaku dominan hegemonic pada seseorang melihat suatu informasi pada media akan menerima secara mentah dan keseluruhan apa yang dia yakini dan lihat pada media tersebut. Narasumber satu, narasumber empat, enam, tujuh, dan narasumber delapan, meyakini bahwa informasi yang diterimanya adalah sesuai dengan apa yang narasumber satu lihat pada akun instagram @perpuseru tersebut.

Narasumber dua pernah mengikuti program PerpuSeru di awal masa kuliahnya, namun memilih untuk tidak meneruskan program tersebut. Dari wawancara tersebut dapat disimpulkan bahwa narasumber dua adalah model negotiated yaitu narasumber tidak sepenuhnya yakin terhadap PerpuSeru namun juga tidak menolak adanya PerpuSeru. Narasumber dua lebih banyak mengetahui tentang PerpuSeru karena pernah terlibat di dalamnya sehingga pesan yang disampaikan oleh PerpuSeru hampir seluruhnya tersampaikan pada narasumber dua.

Hal ini sama dengan narasumber enam Pada kasus narasumber enam yang sudah jauh lebih mengetahui tentang PerpuSeru karena pernah terlibat komunikasi dengan kolega yang berkecimpung di dunia PerpuSeru. Maka, ada proses negosiasi dalam menerima informasi yang disajikan oleh PerpuSeru.

Narasumber tiga adalah anggota CSR program PerpuSeru sehingga jawaban yang diberikan dalam wawancara ini lebih kepada menyamakan persepsi antara encoder yaitu PerpuSeru dan decoder yaitu narasumber yang telah diwawancara. Hasil wawancara dengan narasumber tiga juga digunakan untuk menentukan tersampaikannya atau tidak pesan dari PerpuSeru pada followers sebagai narasumber. Sejauh wawancara yang dilakukan pada sebagian narasumber, diketahui bahwa makna pesan yang diterima memang tidak sepenuhnya sesuai dengan penyampai pesan, namun narasumber juga tidak jauh mengartikan pesan tersebut dari makna utama pesan yang disampaikan. Seperti contohnya, pemahaman narasumber satu dan 2 terkait salah satu postingan di akun @perpuseru berikut:

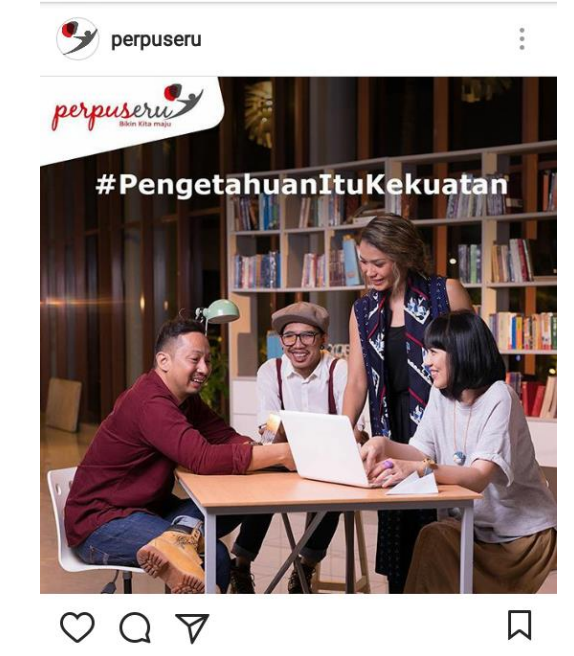

Gambar 2. Salah satu postingan @perpuseru Sumber: PerpuSeru, 2018 
Narasumber satu memaknainya sebagai bagian dari literasi yaitu orang yang kuat harus berilmu salah satunya dengan cara berdiskusi, melalui latar belakang yang mencerminkan perpustakaan dan laptop sebagai visualisasi TIK. Narasumber dua memaknai gambar tersebut sebagai suatu slogan pengetahuan, sumber kekuatan bagi manusia. Narasumber tiga, memberikan penjelasan tentang gambar tersebut, bahwa postingan tersebut ditujukan untuk branding gerakan Cocacola Foundation Indonesia (CCFI) untuk PerpuSeru. Berbedanya persepsi yang terjadi di antara narasumber adalah bagian dari proses decoding suatu pesan yang dapat dimaknai apa saja tergantung dari penerima pesan tersebut. Hasil ini menunjukan bahwa, tidak semua followers PerpuSeru paham betul dengan arti postingan di instagram @perpuseru meskipun secara garis besar followers mengikuti akun @perpuseru karena profilnya yang sudah lebih dahulu diketahui karena nama besar Coca-cola Foundation dan Bill and Melinda Gates Foundation. Di samping programnya yang memang bermanfaat untuk Indonesia.

Secara sederhana, hasil wawancara yang telah dilakukan pada narasumber dapat menjawab bagimana persepsi followers terhadap informasi yang disampaikan melalui media sosial instagram. Dari ketiga narasumber, dapat mewakilkan bagaimana followers menjadi bagian dari @perpuseru. Sebagian followers menjadi bagian dari @perpuseru karena branding nama profil yang ditampilkan. Disamping itu ada beberapa artis yang terlibat di dalamnya. Branding inilah yang mendorong followers untuk terus mengikuti@perpuseru dan mencari tahu lebih banyak terkait akun tersebut.
Sebagian followers mengikuti @ perpuseru karena sudah lebih dulu terlibat dalam program yang ada di PerpuSeru. Terlibatnya followers dalam program ini membuat keinginan untuk juga mengikuti media penyampai pesan tersebut, yaitu instagram untuk diikuti dan menjadi bagian di dalamnya.

Teori decoding-encoding menyebutkan ada tiga macam penerima pesan, yaitu dominan hegemonik, negoisasi, serta opsional. Dalam penelitian yang telah dilakukan ternyata hanya terdapat dua macam tipe penerima pesan, yaitu dominan hegemonik serta negosiasi. Hal ini wajar terjadi karena dalam penerapan suatu teori pada sebuah kasus tertentu tidak akan secara pasti teori tersebut dapat diterapkan seutuhnya. Perbedaan waktu, tempat, serta prosedur penelitian akan mempengaruhi perkembangan teori tersebut.

Tidak seluruhnya apa yang telah disebutkan dalam teori masuk dalam hasil penelitian ini karena tidak selalu isi keseluruhahan teori dapat diterima dalam sebuah penelitian. Perbedaan situasi dan kondisi yang ada menyebabkan sebuah teori terus mengalami kebaruan serta perbedaan sudut pandang hasil yang dicapai. Penelitian ini membuktikan bahwa persepsi seseorang terhadap informasi yang disampaikan melalui media dapat memiliki makna yang berbeda-beda, meskipun dengan jenis informasi yang sama. Instagram memiliki jenis media visual, baik berupa teks, video, maupun gambar, meskipun demikian lebih banyak menggunakan teks dalam penyampaian pesannya. Hal inilah yang membuat makna dari pesan yang tersampaikan tersebut dapat berarti banyak hal. 
Perbedaan persepsi yang diterima oleh followers juga karena penggunaan prasangka yang memungkinkan lingkungan dapat merespon secara umum atau spontan. Hal-hal yang yang mempengaruhinya, diantaranya adalah budaya serta kebiasaan dan kepribadian. Persepsi yang sama mungkin diarahkan pada satu kelompok sasaran, namun penerimaan isi pesan tersebut ternyata tidak secara keseluruhan dianggap sama oleh kelompok tersebut. Berbagai makna dapat diinterpretasikan, meskipun masih dalam suatu lingkup penalaran yang sama.

Followers yang hanya mengikuti informasi instagram mungkin akan lebih memiliki sedikit pengetahuan tentang PerpuSeru yang diterimanya dibanding dengan followers yang mengikuti progamnya. Jumlah besar sedikitnya pengetahuan yang diterima bukan berarti followers tidak mengetahui mengenai @perpuseru, namun pesan yang disampaikan @perpuseru tidak dapat sepenuhnya masuk dan dipahami oleh followers. Sebaliknya, pada followers yang aktif dengan program PerpuSeru atau pernah menjadi bagian dari PerpuSeru, sebagian besar lebih memahami pesan yang disampaikan, serta dapat memberikan respon yang baik dan masukan yang sesuai dengan isi pesan yang disampaikan @perpuseru.

PerpuSeru sebagai pengirim pesan melalui media instagram memiliki pengaruh yang cukup kuat terhadap informasi yang disampaikan, terlebih saat menampilkan icon yaitu Ringgo A. Rahman dan Adinia Wirasti. Secara cepat pengikut dari icon PerpuSeru tersebut juga akan mengikuti apa yang diikuti oleh artisnya, sehingga PerpuSeru memiliki daya tarik yang kuat terhadap masyarakat khususnya yang berhubungan dengan dunia pendidikan, salah satunya melalui perpustakaan.

Tidak banyaknya organisasi yang menampilkan perpustakaan sebagai sasaran utama hal yang akan diinformasikan membuat PerpuSeru menjadi bagian penting di masyarakat yang haus akan pengetahuan, terutama pada bidang pendidikan. Masyarakat atau followers melalui informasi di instagram, akan melihat usaha PerpuSeru dalam membantu pengembangan perpustakaan di daerah. Followers akan memiliki perasaan bahwa perpustakaan di Indonesia masih memerlukan uluran tangan semua pihak untuk menyalurkan pengetahuan.

Tidak samanya persepsi yang dimiliki satu dengan yang lainnya antara followers juga akibat dari cara menafsirkan makna pesan itu sendiri. Sisi psikologi seseorang juga memiliki pengaruh terhadap keberlangsungan cara berpikir seseorang dalam memahami suatu makna. Pada saat pesan sampai pada diri komunikator, psikologi juga melihat ke dalam proses penerimaan pesan, menganalisisnya, dan menjelaskan baik sebagai komunikan untuk diri sendiri maupun orang lain dalam suatu kelompok (Rakhmat, 2009).

Pesan tersebut akan tersampaikan secara tersirat, meskipun followers @ perpuseru tidak selalu memaknai seperti itu. Secara garis besar bahwa pesan yang ingin disampaikan @perpuseru melalui instagram ini telah tersampaikan dengan baik pada masyarakat.

\section{SIMPULAN}

Uraian mengenai persepsi followers akun @perpuseru dilihat dari teori decoding-encoding Stuart Hall dapat 
disimpulkan bahwa pemaknaan pesan oleh followers sangat sesuai dengan apa yang dikehendaki oleh @perpuseru karena setiap followers memiliki banyak imajinasi dan pemikiran terhadap media yang dimilikinya. Secara luas instagram digunakan sebagai media promosi dalam setiap pencapaian PerpuSeru. Instagram juga digunakan untuk menyampaikan pesan terkait kegiatan yang dilakukan atau informasi terkini tentang suatu pengetahuan. PerpuSeru memiliki jargon atau moto yang disebarkan secara luas melalui berbagai media sosial maupun website agar diketahui user. Hal ini membuat jargon tersebut mudah diingat dan familiar ketika disampaikan dalam suatu kegiatan meskipun tidak selalu user yang mengetahui jargon tersebut mengetahui arti yang ingin disampaikan oleh PerpuSeru. Sesuai dengan penelitian yang telah dilakukan masing-masing narasumber, meskipun sama-sama followers akun @perpuseru namun memiliki pemahaman dan konsep yang berbeda terkait alasan dan pengetahuannya tentang PerpuSeru. Followers memiliki gambaran dan persepsi sendiri tentang apa itu PerpuSeru dan kegiatan apa yang telah dilakukan hingga saat ini. Banyaknya followers yang ada pada media sosial instagram @perpuseru tidak menjamin semuanya adalah followers dengan kriteria dominan hegemonic. Terdapat follower yang dominan hegemonic dan negotiated dalam akun @perpuseru dapat dilihat dari penerimaan pesan yang disetujui bagaimanapun bentuk dan isinya oleh sebagian followers, serta negosiasi dari sebagian lainnya. Adanya dua kriteria pada followers akun @perpuseru menegaskan bahwa masih ada satu kriteria lagi yang tidak terdapat pada followers media tersebut yaitu opsional. Hal ini disebabkan karena followers pada akun @perpuseru dengan sadar mengikuti akun media tersebut tanpa adanya paksaan, sehingga tidak adanya penolakan atau bias terhadap informasi yang disampaikan. Teori decodin-encoding masih bisa masuk dalam media saat ini, meskipun tidak semua isi teori dapat diterapkan. Hal ini karena adanya perubahan dan pergeseran bentuk media. Media menjadi penghubung antara informasi dengan user. Saat informasi yang terdapat pada media tidak dapat dipahami dengan baik oleh user, maka akan ada berbagai bentuk hasil yang dapat diterima user. Masih banyaknya hal yang dapat digali sebagai wawasan kita terhadap media, penelitian selanjutnya dapat dilakukan dengan melihat sudut pandang admin media sosial dalam penyampaian pesan melalui media dengan berbagai teori yang ada.

\section{DAFTAR PUSTAKA}

Adi, A., \& Ali, H. (2017). 45 juta pengguna instagram, Indonesia pasar terbesar di Asia. Retrieved July 29, 2017, from https:/ / bisnis.tempo.co/read/news/ 2017/07/26/090894605/45-jutapengguna-instagram-indonesia-pasarterbesar-di-asia

Ahmad, F. (2018). Peran program perpuseru CCFI dalam upaya peningkatan kualitas layanan di Dinas Perpustakaan dan Kearsipan Kabupaten Gunung Kidul (Skripsi). Universitas Islam Negeri Sunan Kalijaga, Yogyakarta. Retrieved from http://digilib.uinsuka.ac.id/29808/1/13140062_BABI_IV-atau-V_DAFTAR-PUSTAKA.pdf Akçayir, M., Dündar, H., Akçayir, G. (2016). What makes you a digital native? Is it enough to be born after 1980? Computers in Human Behavior, $60(8)$,

435-440. 
https:// doi.org/https:// doi.org/10.1 016/j.chb.2016.02.089

Darmayanti, R. (2016). Membangun budaya literasi informasi bagi masyarakat kampus. Jurnal Igra', 10(1), 92-101

Firdayanti, R. (2012). Persepsi risiko melakukan e-Commerce dengan kepercayaan konsumen dalam membeli produk fashion online. Journal of Social and Industrial Psychology, 1(1), 1-7.

Galih, A. P. (2018). Model knowledge sharing pada grup Facebook Backpacker Dunia. Kajian Informasi \& Perpustakaan, 6(1), 59-76. Retrieved from

http://jurnal.unpad.ac.id/jkip/articl e/view/14699/8257

Hall, S. (2001). Encoding-decoding: Media and cultural studies. (Meenakshi Gigi Durham \& Douglas M. Kellner, Ed.). Massachusetts: Blackwell Publishers Inc.

Hall, S. (2011). The neo-liberal revolution. Cultural Studies, 25(6), 705-728. https:// doi.org/https:// doi.org/10.1 080/09502386.2011.619886

Humaidah. (2017). Pengaruh promosi perpustakaan melalui media sosial terhadap pemanfaatan perpustakaan di Perpustakaan Kementerian Perindustrian R.I. (Skripsi). UIN Syarifhidayatullah, Jakarta. Retrieved from http://repository.uinjkt.ac.id/dspace /bitstream/123456789/34439/2/HU MAIDAH-FAH.pdf

Kartikasari, N. (2012). Audit Komunikasi Program Corporate Social Responsibility (Studi Peran Public Relations pada Pt. Coca-Cola Amatil Indonesia) (Doctoral dissertation, Program Studi Komunikasi FISKOM-UKSW).

Kementerian Pendayagunaan Aparatur Negara dan Reformasi Birokrasi
Republik Indonesia. Pedoman pemanfaatan media sosial instansi pemerintah, Pub. L. No. 83 (2012). Indonesia. Retrieved from http://bkpsdm.belitungkab.go.id/do wnload-file/ 82

Khoir, S. (2018). Perilaku dan manajemen informasi dalam era normal baru. Yogyakarta: Universitas Gadjah Mada. Retrieved from https://repository.ugm.ac.id/id/epri nt/274265/contents

Krisbiantoro, D., Suyanto, M., \& Luthfi, E. T. (2015). Evaluasi keberhasilan implementasi sistem informasi dengan pendekatan HOT Fit model (Studi kasus: Perpustakaan STMIK AMIKOM Purwokerto). Proceedings Konferensi Nasional Sistem dan Informatika (KNSEI).

Moleong, L. J. (2010). Metodologi penelitian kualitatif. Bandung: Rosda Karya.

Nurpratama, M., R., \& Adriyana, L, . (2017). Using instagram for library: Benefits, strategis, and policies. In Prosiding ICOLAIS 2017. Jakarta: Universitas Indonesia.

Permana, A. N., Yusup., P. M., \& Kurniasih, N. (2016). Proses pendalaman informasi berbasis informasi awal LINE@ BEM FIKOM UNPAD. Kajian Informasi \& Perpustakaan, 4(1), 11-20. Retrieved from

http://jurnal.unpad.ac.id/jkip/articl e/view/11627/5455

PerpuSeru. (2018). perpuseru. Retrieved from

https://www.instagram.com/perpus $\mathrm{eru} /$ ?hl=id

Pujiati, H., Astutiningsih, I., \& Sari, M. N. (2015). The representation of fandom discourse in rainbow rowell's fangirl. Publikasi Budaya, 3(2), 52-62. Retrieved 
from

https://media.neliti.com/media/pub lications/191379-EN-representasiwacana-fandom-dalam-novel-f.pdf

Rakhmat, J. (2009). Psikologi komunikasi. Bandung: Remaja Rosdakarya.

Rianto, P. (2016). Media baru, visi khalayak aktif dan urgensi literasi media. Jurnal Komunikasi Ikatan Sarjana Komunikasi Indonesia, 1(2), 9096.

Rusmana, A. (2015). Penipuan dalam interaksi melalui media sosial (kasus peristiwa penipuan melalui media sosial dalam masyarakat berjejaring). Jurnal Kajian Informasi dan Perpustakaan, 3(2), 187-194. doi:http://dx.doi.org/10.24198/jkip. v3i2.9994

Safira, F., Saleh, C., \& Suprapto, A. (2015). Implementasi program perpuseru dalam upaya meningkatkan pelayanan perpustakaan (studi kasus pada corporated social responsibility Coca Cola Foundation Indonesia di Perpustakaan Kabupaten Sidoarjo). Jurnal Administrasi Publik, 3(5), 770774. Retrieved from http:/ / administrasipublik.studentjou rnal.ub.ac.id/index.php/jap/article/ view/863

Statista. (2018). Digital in 2018 profile of instagram users by age. Retrieved November 19, 2018, from https:/ / www.statista.com/statistics/ 248769/age-distribution-ofworldwide-instagram-users /

Subrata, G. (2009). Upaya pengembangan kinerja pustakawan perguruan tinggi di era globalisasi informasi. Jurnal Pustakawan Perpustakaan UM, 1(1), 112.

Tunardjo, M. (2018). Pengembangan perpustakaan kabupaten/kota dan perpustakaan desa/kelurahan berbasis program perpustakaan seru (PerpuSeru) di Provinsi Nusa Tenggara Timur. Jurnal Flobamora, 2(1), 9-19.

Watie, E. D. S. (2016). Komunikasi dan media sosial (communications and social media). Jurnal The Messenger, 3(2), 69-74. 
